Pakistan's scientists respond warily to World Bank reforms

London. The Pakistan government has been advised by the World Bank to carry out a broad-ranging shake-up of its research institutions in a belated attempt to harness science to wealth creation.

The changes, if carried through, would represent the most far-reaching upheaval since reforms in the late $1950 \mathrm{~s}$. The centrepiece would be the closure of Pakistan's oldest and largest multidisciplinary research organization, the 43-year-old Pakistan Council for Scientific and Industrial Research (PCSIR), which lists the development of Slimfast, an effective weight-reducing diet, as its key achievement of 1994.

But the proposals have caught unawares the country's scientific community. While giving a cautious welcome to the proposed changes, some scientists believe the government appears to be abdicating its responsibility for promoting science.

While the government insists it is still considering the proposals, an aide-mémoire from a recent World Bank mission to Pakistan in July suggests that changes are well advanced. Their main emphasis is on restructuring the PCSIR's nine laboratories into efficient, single-discipline institutions, focusing on the strategic areas of research in glass, biotechnology, applied chemistry, fuel technology, pharmaceuticals and minerals.

Each institute would be managed by a chief executive officer and guided by a board of directors. They would be presided over by a newly created Pakistan Research and Technology Foundation whose principal aims would be technology "foresight and R\&D project management". Of the estimated cost of US $\$ 80$ million, $\$ 18$ million would come from the private sector, $\$ 44$ million from World Bank loans, and the remainder from the government.

Basit Hasan, a spokesman for the Pakistan Association for Scientists and Scientific Professionals (PASSP), says many researchers in Pakistan were not even informed of the World Bank's proposals.

Many believe they are being blamed for PCSIR's failure to turn science into commercial applications. But Hasan says this is unfair, as the government, still lacking a minister for science, has made little effort recently to bring industry closer to research. The PCSIR, he adds, had been expected to develop world-beating technologies on a budget of less than $\$ 10$ million a year.

Javed Jabbar, a former minister for science and architect of the National Technology Policy, says that the World Bank proposal that the private sector should take on the main responsibility for bailing out science is unworkable in Pakistan.

Ehsan Masood

\title{
Climate critics claim access blocked to unpublished data
}

Washington. Researchers who do not believe human activity is having a significant impact on global climate change have been denied access to the latest data from British climate models used by the Intergovernmental Panel on Climate Change (IPCC), a congressional hearing was told last week.

The allegation was made by Patrick Michaels of the University of Virginia, an outspoken sceptic about man-made climate change. But the group that carried out the research has justified not making the data available on the grounds that it had not yet been published in the scientific literature.

Michaels was speaking at a hearing of the House of Representatives Science Committee's energy and environment subcommittee, chaired by Dana Rohrabacher

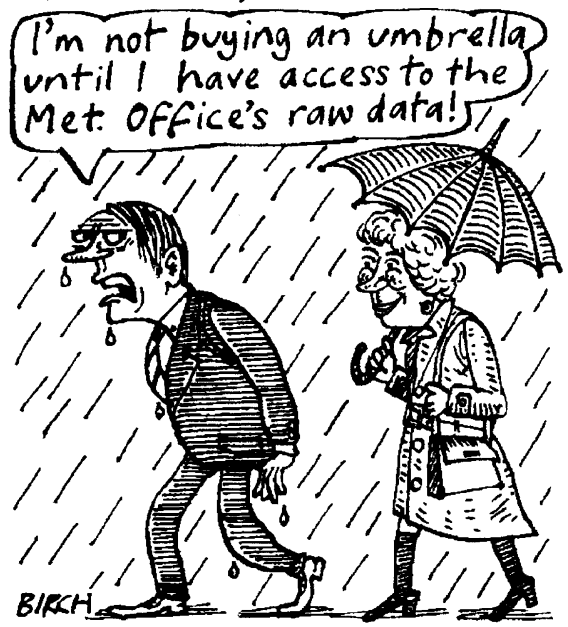

(Republican, California). The hearing was the second of three on "scientific integrity and public trust".

According to Rohrabacher, the purpose of the hearing was to ensure "that both sides are presented" on the climate change issue. But Democrats and environmental pressure groups say that the hearing, like an earlier one on ozone depletion, merely gave excessive prominence to the views of a noisy handful of "dissident" scientists.

Michaels told the subcommittee that "taxpayer-supported organizations" were denying "critical scientists" access to data required quantitatively to review new syntheses on global warming. He said he had asked John Mitchell of the UK Meteorological Office on 10 May for detailed output data from an improved climate model then being used by the IPCC in preparation of its Second Scientific Assessment.

Michaels wanted data from the model which had been modified to take account of the cooling effects of sulphate aerosols - to enable him to test his theory that the improved model would still predict too much warming at high latitudes.
Mitchell declined the request on the grounds that the data had not yet been published; the paper appeared in Nature in the issue of 10 August (376, 501; 1995). But Michaels, speaking after the hearing, argued that he should have been given access to the data earlier on the ground that the work had been accepted for publication and was, in any case, already being used by the IPCC, whose work he was seeking to review.

Tim Roemer (Democrat, Indiana) told Michaels that his "problems with the UK" were beyond the jurisdiction of the US Congress, but Michaels countered that the work was funded by United States taxpayers. In fact, the Mitchell work was funded by the UK Department of the Environment, but the IPCC is a United Nations organization, and, therefore, would be funded by US taxpayers if the US paid its dues to the UN.

Disputing the theory of global warming caused by human activity, Michaels told the hearing that he expected "a change of paradigm towards the idea that the Earth is a great deal more resilient than we thought". But Jerry Mahlman, director of the Geophysical Fluid Dynamics Laboratory at Princeton, New Jersey, replied that anthropogenic global warming is "a harsh and inexorable reality".

In addition to their disagreement on the science, Roemer and Rohrabacher also clashed on budget matters, with the former claiming that the hearing was being held too late, as congressional action was virtually complete on global change research.

A key feature of the series of hearings has been various challenges to the integrity of the scientific basis to claims about contemporary environmental threats. But Lynn Rivers (Democrat, Michigan) turned the tables by calling into question the credibility of witnesses making such allegations.

In particular, Rivers said that enquiries by subcommittee staff had failed to substantiate a charge by Sally Baliunas of Harvard University that she had lost funding because of her views on ozone depletion. "Despite the allegations by Drs Baliunas and Michaels, the subcommittee has received exactly zero evidence that there is some sort of cabal among environmental scientists to keep these critics unfunded and voiceless," she said afterwards.

Rivers, who tried unsuccessfully to reintroduce the issue of Baliunas's allegations into last week's hearing, added that these critics "are not involved in scientific debates and discourse because they find it easier to play to the popular press and to seek funding from groups whose interests align with these scientists' predispositions".

Colin Macilwain 